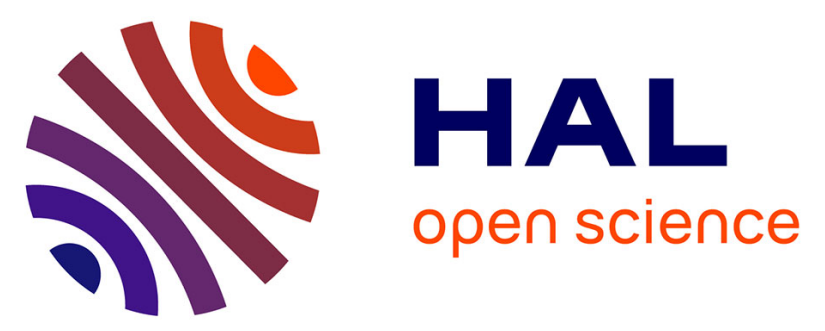

\title{
Changes in the nutrient ratios and phytoplankton community after declines in nutrient concentrations in an eutrophic semi-enclosed bay in Hong Kong
}

\author{
Alle A.Y. Lie, C. Kim Wong, Jackie Y.C. Lam, J.H. Liu, Y.K. Yung
}

\section{To cite this version:}

Alle A.Y. Lie, C. Kim Wong, Jackie Y.C. Lam, J.H. Liu, Y.K. Yung. Changes in the nutrient ratios and phytoplankton community after declines in nutrient concentrations in an eutrophic semi-enclosed bay in Hong Kong. Marine Environmental Research, 2011, 71 (3), pp.178. 10.1016/j.marenvres.2011.01.001 . hal-00673201

\section{HAL Id: hal-00673201 https://hal.science/hal-00673201}

Submitted on 23 Feb 2012

HAL is a multi-disciplinary open access archive for the deposit and dissemination of scientific research documents, whether they are published or not. The documents may come from teaching and research institutions in France or abroad, or from public or private research centers.
L'archive ouverte pluridisciplinaire HAL, est destinée au dépôt et à la diffusion de documents scientifiques de niveau recherche, publiés ou non, émanant des établissements d'enseignement et de recherche français ou étrangers, des laboratoires publics ou privés. 


\section{Accepted Manuscript}

Title: Changes in the nutrient ratios and phytoplankton community after declines in nutrient concentrations in an eutrophic semi-enclosed bay in Hong Kong

Authors: Alle A.Y. Lie, C. Kim Wong, Jackie Y.C. Lam, J.H. Liu, Y.K. Yung

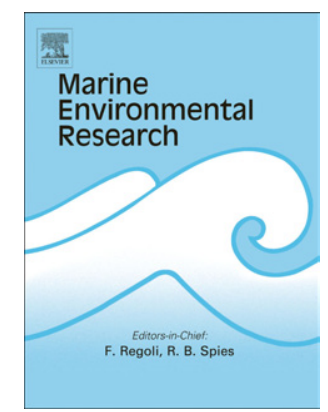

PII:

S0141-1136(11)00003-1

DOI:

10.1016/j.marenvres.2011.01.001

Reference: MERE 3497

To appear in: Marine Environmental Research

Received Date: 17 June 2010

Revised Date: 5 January 2011

Accepted Date: 12 January 2011

Please cite this article as: Lie, A.A., Wong, K., Lam, J.Y., Liu, J.H., Yung, Y.K. Changes in the nutrient ratios and phytoplankton community after declines in nutrient concentrations in an eutrophic semi-enclosed bay in Hong Kong, Marine Environmental Research (2011), doi: 10.1016/ j.marenvres.2011.01.001

This is a PDF file of an unedited manuscript that has been accepted for publication. As a service to our customers we are providing this early version of the manuscript. The manuscript will undergo copyediting, typesetting, and review of the resulting proof before it is published in its final form. Please note that during the production process errors may be discovered which could affect the content, and all legal disclaimers that apply to the journal pertain. 
1 Changes in the nutrient ratios and phytoplankton community after declines in nutrient

2 concentrations in an eutrophic semi-enclosed bay in Hong Kong

3

4 Alle A. Y. Lie ${ }^{1 *}$, C. Kim Wong ${ }^{1}$, Jackie Y. C. Lam², J.H. Liu ${ }^{2}$ \& Y. K. Yung ${ }^{2}$ 5

$6 \quad{ }^{1}$ Department of Biology, The Chinese University of Hong Kong, Shatin, Hong Kong

$7 \quad{ }^{2}$ Water Policy and Science Group, Hong Kong Government Environmental Protection

8 Department, Revenue Tower, 5 Gloucester Road, Wan Chai, Hong Kong

9 ^Current address: Department of Biological Sciences, University of Southern

10 California, 3616 Trousdale Parkway, Los Angeles, 90089-0371, CA, USA

11

12 *Corresponding author:

13 email: alie@usc.edu

14 Tel.: +852 26096773; Fax: +852 26035391 
15 Abstract

17 Tolo Harbour is a landlocked bay with poor tidal flushings in the northeastern part of

18 Hong Kong. During the 1980s, excessive nutrient loading led to dramatic increase in

19 nutrient concentrations, accompanied by lower N:P ratios, higher algal biomass and

20 shifts in the phytoplankton community. We studied the effects of nutrient loading

21 reduction measures on nutrient concentrations, nutrient ratios and phytoplankton

22 dynamics in Tolo Harbour by comparing data collected before the full implementation

23 of nutrient loading reduction measures (1986-1997) to those after the implementation

24 (1998-2008). Such measures led to declines in nutrient concentrations, changes in

$25 \mathrm{~N}: \mathrm{P}$ and $\mathrm{N}: \mathrm{Si}$ ratios, lower chlorophyll- $a$ concentrations and fewer algal blooms.

26 Diatoms were the most abundant phytoplankton group in Tolo Harbour both before

27 and after declines in nutrient concentrations. The density of dinoflagellates did not

28 change, but substantial increase in other algal group abundance was recorded.

30 Keywords: Nutrients, Nutrient ratios, Phytoplankton, Eutrophication, Coastal waters,

31 Tolo Harbour. 


\section{Introduction}

Eutrophication is a common consequence of anthropogenic activities on water bodies, and is widely regarded as the most wide-spread water quality problem globally (Carpenter et al., 1999; Smith et al., 1999; Smith, 2003). The most common effects of eutrophication are increases in phytoplankton productivity and biomass, which in turn produce other adverse effects such as decreases in water transparency, increases in the frequency of bottom hypoxia or anoxia and loss of various aquatic organisms (Nixon, 1995; Smith et al., 1999; Smith, 2003). Numerous recent studies have linked eutrophication to algal blooms which cause ecological and economical damages (e.g. Anderson et al., 2008; Cloern, 2001; Smith et al., 1999). Nutrient loadings may cause changes in the nutrient ratios (Justić et al., 1995; Turner, 2002), and such changes may affect the species composition of the phytoplankton community and higher trophic levels (Officer and Ryther, 1980; Philippart et al., 2000; Smith, 1983; Turner et al., 1998; Turner, 2002). Although eutrophication in freshwater systems has been studied extensively and intensively during the past few decades, with many studies reporting on the effects of increased or decreased nutrient concentrations in lakes (e.g. Battarbee et al., 2005; Carvalho and Kirika, 2003; Jeppesen et al., 2005; Jeppesen et al., 2007; Mehner et al., 2001), similar kinds of 
51 studies, with long-term monitoring data, are relatively scarce in marine coastal

52 ecosystems (Examples summarized by Smith et al., 1999).

53 Hong Kong is one of the most densely populated cities in the world. Intensive

54 urbanization and industrialization during the past few decades has dramatically

55 increased nutrient input into Hong Kong's coastal seas (Lee et al., 2006). The concern

56 on the coastal water quality led to the initiation of a marine water quality monitoring

57 program by the Hong Kong Environmental Protection Department in the 1980s (Lee

58 et al., 2006). One of the intensely monitored zones is Tolo Harbour, a landlocked bay

59 in the northeastern corner of Hong Kong.

60 Tolo Harbour consists of a shallow inner bay, with a mean depth of 6-7 m, and a

61 narrow tidal channel which opens into the neighboring Mirs Bay. Urban development

62 and large-scale reclamation around Tolo Harbour began in the 1970s. Sewage

63 discharge from the expanding population caused a sharp increase in nutrient input

64 (Lam and Ho, 1989; Wear et al., 1984). Hodgkiss and Yim (1995) estimated a daily

65 nitrate and phosphate loading of $32,460 \mathrm{~kg}$ and $3,190 \mathrm{~kg}$ respectively into Tolo

66 Harbour. In addition to nutrient inputs, the bottleneck topography of the Tolo Harbour

67 leads to poor tidal exchange rates and persistence of high nutrient concentrations (Lee

68 et al., 2006). Increased nutrient concentrations produced algal blooms, with

69 dinoflagellates such as Noctiluca scintillans being the most common causative species 
70 during the 1980s and 1990s (Lam and Ho, 1989; Liu and Wong, 2006). Although

71 Noctiluca are generally considered as heterotrophic (Kiørboe and Titelman, 1998),

72 strains of Noctiluca miliaris with phytosynthetic symbionts have been found in

73 Southeast Asia (Sweeney, 1971; Hansen et al., 2004), which may benefit from

74 increased nutrient concentrations (Sriwoon et al., 2008). In addition, the increased

75 nutrient concentrations would also favor the growth of diatoms and other prey for $N$.

76 scintillans (Liu and Wong, 2006).

77 Wear et al. (1984) reported mean concentrations of $\mathrm{NO}_{\mathrm{x}}-\mathrm{N}$ and $\mathrm{PO}_{4}-\mathrm{P}$ in the

78 inner Tolo Harbour to be $0.05 \mu \mathrm{M}$ and $0.01 \mu \mathrm{M}$ respectively during 1974-1976. By

79 early 1990s, annual mean concentrations have increased to $19.99 \mu \mathrm{M}$ for inorganic

80 nitrogen and $1.94 \mu \mathrm{M}$ for $\mathrm{PO}_{4}-\mathrm{P}$ (Hong Kong Environmental Protection Department,

81 1991). Moreover, $\mathrm{PO}_{4}-\mathrm{P}$ values as high as $10.65 \mu \mathrm{M}$ have been reported in Tolo

82 Harbour in 1978-1979 (Hodgkiss and Chan, 1983). Decreasing trends in N:P ratio

83 were recorded during the 1980s and early 1990s (Hodgkiss and Chan, 1997; Yung et

84 al., 1997), and was considered to be caused by excessive P input (Hodgkiss and Chan,

85 1983, Hodgkiss and Yim,1995). Some researchers noted that the observed changes in

86 nutrient parameters had caused a shift in the species composition of the phytoplankton

87 community, with diatoms gradually replaced by dinoflagellates, (Chan and Hodgkiss,

88 1987; Hodgkiss and Ho, 1997; Lam and Ho, 1989), although a review of the data 
89 collected by the Hong Kong Environmental Protection Department did not reveal such

90 a shift in the phytoplankton during 1982-1992 (Yung et al., 1997).

92 halt the declining water quality of Tolo Harbour. Two of the most important

93 components of the action plan were the modification of existing sewage treatment

94 works processes (implemented in 1992) and the Tolo Harbour Effluent Export

95 Scheme (Chau, 2007). Commissioned in the mid-1990s and became fully operational

96 in 1998, the Tolo Harbour Effluent Export Scheme allows treated sewage from two

97 large sewage treatment works to be exported via pipelines for discharge outside of

98 Tolo Harbour. Nitrogen input into Tolo Harbour was reduced to $\sim 1000 \mathrm{~kg} \mathrm{day}^{-1}$ by

992000 (Hong Kong Environmental Protection Department, 2006).

100 In this study, data collected from four sampling stations in Tolo Harbour during

101 the period from 1986-2008 were analyzed to provide information on the long-term

102 changes in the hydrography and phytoplankton dynamics. Conditions before

103 (1986-1997) and after (1998-2008) the full implementation of the Tolo Harbour

104 Effleunt Export Scheme were compared to: (1) determine whether declines in nutrient

105 concentrations had led to changes in the nutrient ratios, and (2) identify shifts in the

106 phytoplankton community that may be related to changes in the nutrient

107 concentrations and ratios. Overall changes of the hydrography and phytoplankton 
108 community in Tolo Harbour after declines in nutrient concentrations were also

109 compared to those reported in other ecosystems after recovery from eutrophication.

110

111 2. Materials and Methods

112

113 All data were provided by the Hong Kong Environmental Department. Four

114 sampling stations in Tolo Harbour, TM3, TM4, TM6 and TM8 (Fig. 1), were sampled

115 frequently, mostly once each month, but irregularly from 1982-1992. Monthly means

116 were calculated for each station. Physico-chemical parameters, including temperature,

117 salinity, $\mathrm{pH}$ and dissolved oxygen concentration (DO), were recorded at $1 \mathrm{~m}$ below

118 the water surface, mid-depth in the water column and $1 \mathrm{~m}$ above the bottom by a

119 SEACAT 19plus CTD water profiler (Sea-BIRD Electronics). Water samples were

120 also collected at the three depths using Niskin-type water bottles for the determination

121 of $\mathrm{BOD}_{5}$, chlorophyll- $a$ concentration, suspended solids concentration, and the

122 concentrations of $\mathrm{NO}_{3}-\mathrm{N}, \mathrm{NH}_{4}-\mathrm{N}$, total inorganic nitrogen (TIN), total nitrogen (TN),

$123 \mathrm{PO}_{4}-\mathrm{P}$, total phosphorus (TP) and $\mathrm{SiO}_{2}$. The data from the three depths were averaged

124 into depth-averaged data. Values from the bottom depth were also analyzed for DO

125 and $\mathrm{BOD}_{5}$ to provide information on hypoxia at the water bottom. Measurement of

$126 \mathrm{BOD}_{5}$, nutrient concentrations, chlorophyll- $a$ concentration and suspended solids 
127 concentration were carried out by the Hong Kong Government Laboratory using

128 procedures described by APHA (American Public Health Association et al. 1998).

129 Data on algal bloom occurrences were obtained from the Hong Kong Agriculture,

130 Fisheries and Conservation Department, and were independent from our data. Such

131 data on algal bloom occurrences was based on sighting reports of seawater

132 discoloration, and may therefore underestimate algal bloom occurrences. It also does

133 not contain taxonomic information regarding the algal bloom.

134

135 (Insert Fig. 1 here)

136

137 Water samples from $1 \mathrm{~m}$ below the water surface were preserved in Lugol's

138 iodine solution (1: $100 \mathrm{ml}$ ). In the laboratory, phytoplankton were examined in an

139 Utermöhl counting chamber under an inverted microscope, and the densities of

140 diatoms, dinoflagellates and other algal groups (Algae that were neither diatoms nor

141 dinoflagellate) were counted. Phytoplankton data for TM6 was only available after

142 1993, while data collection for other stations have began in 1986 (TM8) and 1988

143 (TM3 and TM4).

144 Two-way ANOVA was used to test for temporal differences before and after

145 nutrient loading reduction, as well as the spatial differences among sampling stations 
146 in various water quality and phytoplankton parameters. Tukey's test was used for

147 multiple comparison between sites. Kendall's correlation was used to test the

148 correlation between phytoplankton and water quality variables.

149

150 3. Results

151

152 In general, physico-chemical, biological and nutrient parameters showed similar

153 changes among the four sampling stations after nutrient loading reduction (Table 1).

154 Temperature, salinity, bottom DO and $\mathrm{TIN} / \mathrm{PO}_{4}$ increased at all stations after nutrient

155 loading reduction, while $\mathrm{pH}, \mathrm{BOD}_{5}$, chlorophyll- $a$ concentrations, all nutrient

156 concentrations and $\mathrm{TIN} / \mathrm{SiO}_{2}$ decreased. $\mathrm{DO}$ and $\mathrm{SiO}_{2}$ concentration did not differ

157 significantly between the two time periods and among the stations respectively $(p>$

158 0.05). All other parameters showed significant differences both temporally and

159 spatially, with most $p$ values $<0.001$. Comparison among sampling stations revealed a

160 general trend of improvement in water quality, marked by changes such as decreasing

161 nutrient concentrations and increasing DO and secchi depth, from TM3 to TM8.

162

163 (Insert Table 1 here) 
$166 \mathrm{PO}_{4}-\mathrm{P}$ and total $\mathrm{P}$ ) concentrations were high, especially at TM3 and TM4, prior to

167 nutrient loading reduction (Fig. 2). Concentrations decreased noticeably within a year

168 after the full implementation of the sewage export scheme, and have remained at

169 relatively low levels in recent years. $\mathrm{N}$ and $\mathrm{P}$ concentrations differed markedly among

170 stations before nutrient loading reduction, but the differences became less apparent

171 afterwards. $\mathrm{SiO}_{2}$ concentrations did not appear to differ among stations before nutrient

172 loading reduction. $\mathrm{NO}_{3} / \mathrm{NH}_{4}$ fluctuated widely during the entire study period, but the

173 value was generally lowest at TM3 and highest at TM8 (Fig. 3). In contrast, TIN/PO

174 and $\mathrm{TIN} / \mathrm{SiO}_{2}$ showed much clearer increasing and decreasing trends respectively (Fig.

175 3). TIN/ $\mathrm{PO}_{4}$ decreased gradually from between 1986 and 1996, but have returned to

176 approximately the $16: 1$ Redfield N:P ratio after declines in nutrient concentrations.

177 Declines in nutrient concentrations reduced the among-station differences in TIN/SiO 2

178 and the values at all stations were well below the 1:1 Redfield ratio for N:Si.

180 (Insert Fig. 2 and Fig. 3 here)

182 Chlorophyll- $a$ concentrations and densities of different phytoplankton groups

183 exhibited varying trends temporally (Figs. 4 and 5 respectively). The lack of apparent 
184 similar trends between chlorophyll- $a$ concentrations and phytoplankton densities may

185 be due to the fact that chlorophyll- $a$ data were depth-averaged, while phytoplankton

186 data were from the surface only. In general, the concentrations of chlorophyll- $a$ and

187 densities of all phytoplankton groups were highest at TM3 and lowest at TM8.

188 Dinoflagellate density at TM3 increased to two major peaks of $>10,000$ cells $\mathrm{ml}^{-1}$ in

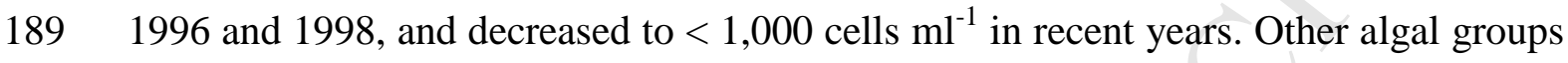

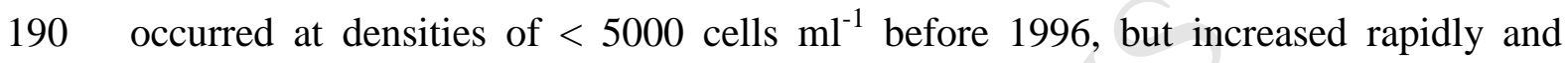

191 considerably after 1996 . Density at TM3 remained $>6,000$ cells ml ${ }^{-1}$ after declines in

192 nutrient concentrations. As diatoms were the most abundant group, the density of total

193 phytoplankton exhibited temporal and spatial patterns more similar to those of

194 diatoms than those of dinoflagellates and other algal groups. Declines in nutrient

195 concentrations did not affect the density of dinoflagellates significantly, but densities

196 of diatoms, other algal groups and total phytoplankton all showed significant increase

197 after declines in nutrient concentrations. Despite a significant increase in total

198 phytoplankton density, the number of algal blooms recorded in Tolo Harbour dropped

199 significantly from a mean of 15.8 before nutrient loading reduction to 7.6 (Paired

200 t-test, $p=0.02$ ) afterwards. No specific phytoplankton group or genus identified in the

201 study could be concluded to be restricted to a particular station. Diatom genera

202 common in all four stations and with average densities $>1,000$ cells ml $^{-1}$ in TM3 and 
$203>600 \mathrm{ml}^{-1}$ in TM8 included Cerataulina, Chaetoceros, Pseudo-nitzschia,

204 Leptocylindrus and Thalassiosira. Prorocentrum and Scrippsiella were the most

205 abundant dinoflagellate genera in all stations. Average density was $>1,000$ cells ml $^{-1}$

206 in TM3 and > 250 cells ml ${ }^{-1}$ in TM8 for Prorocentrum, and $>700$ cells ml ${ }^{-1}$ in TM3

207 and > 100 cells $\mathrm{ml}^{-1}$ in TM8 for Scrippsiella. The dinoflagellates Gymnodinium,

208 Gyrodinium and Protoperidinium were also frequently found at all stations, but their

209 average densities were much lower. Small flagellates represented the most abundant

210 and frequently recorded other algal group in the samples.

211

212 (Insert Fig. 4 and Fig. 5 here)

213

214 Hong Kong is characterized by a warm wet season from April to September, and

215 a relatively dry and cool season for the rest of the year. However, when plots of

216 seasonal means of nutrient concentrations and phytoplankton densities were made, no

217 apparent and general trend could be identified (Data not shown).

218 Kendall's correlation did not reveal any strong or obvious trends between

219 phytoplankton variables and various parameters (Table 2). Results for TM3 and TM4

220 seemed to oppose those for TM6 and TM8 at times. For instance, correlation between

221 phytoplankton variables and $\mathrm{DO}$ and $\mathrm{BOD}_{5}$ were usually positive at TM3 and TM4, 
222 but negative at TM6 and TM8, and vice versa with the results for $\mathrm{SiO}_{2}$. It is also not

223 uncommon to find contradicting results between phytoplankton cell densities and

224 chlorophyll- $a$ concentrations due to the different trends exhibited by these two

225 parameters. Correlation between phytoplankton variables and nutrient variables were

226 mostly negative in all stations except TM6. Most phytoplankton variables at TM3 and

227 TM4 correlated significantly and negatively with nutrient concentrations. In TM6,

228 chlorophyll- $a$ concentrations correlated negatively with $\mathrm{NO}_{3}-\mathrm{N}$ and $\mathrm{NH}_{4}-\mathrm{N}$

229 concentrations, while dinoflagellate densities correlated positively with total $\mathrm{N}, \mathrm{PO}_{4}-\mathrm{P}$

230 and total $\mathrm{P}$ concentrations. $\mathrm{NO}_{3} / \mathrm{NH}_{4}$ correlated negatively with the densities of all

231 groups of phytoplankton at TM3, and positively with diatom densities at TM6 and

232 TM8. TIN/PO $/ \mathrm{PO}_{4}$ correlated positively with other algal group densities in all stations.

$233 \mathrm{TIN} / \mathrm{SiO}_{2}$ correlated negatively with phytoplankton densities in all stations, but

234 exhibited especially strong negative correlations with the densities of dinoflagellates,

235 other algal groups and total phytoplankton at TM3 and TM4. Kendall's correlations

236 between the number of algal blooms and all parameters were also determined.

237 Surprisingly, the number of algal blooms did not correlate significantly with

238 phytoplankton densities, nutrient concentrations and nutrient ratios. It correlated

239 weakly with $\mathrm{pH}(\mathrm{r}=0.313)$ and bottom DO $(\mathrm{r}=0.305)(p<0.05)$, and strongly with

$240 \mathrm{BOD}_{5}(\mathrm{r}=0.513)$ and chlorophyll- $a$ concentration $(\mathrm{r}=0.417)(p<0.01)$. 


\section{Discussion}

4.1. Temporal and spatial variations in marine water quality and phytoplankton

densities

TM8, all parameters show high temporal variations and do not exhibit an apparent

251 trend except changes due to nutrient loading reduction measures. Our data set is

252 unable to explain the cause of specific events such as the relatively lower nutrient

253 concentrations during 1989 (Fig. 2), and the rise in phytoplankton densities in 1995

254 (Fig. 5), which may be due to isolated algal bloom events that inflated the annual

255 mean value. Both of these parameters may also be affected by factors such as water

256 current, weather conditions and anthropogenic activities that are not available in our 257 data set.

258 Changes in various physico-chemical and biological parameters, especially 259 nutrient concentrations, after the implementation of the Tolo Harbour Action Plan 
260 suggested that nutrient loading reduction measures had led to water quality

261 improvement in Tolo Harbour. While Hu et al. (2001) warned that recovery after

262 nutrient loading reduction in Tolo Harbour may be slowed due to nutrients released

263 into the water column from contaminated sediments, $\mathrm{N}$ and $\mathrm{P}$ concentrations appeared

264 to decrease quite rapidly (Fig. 2) after the full implementation of the Tolo Harbour

265 Effluent Export scheme. Surprisingly, although chlorophyll- $a$ concentrations had

266 decreased after declines in nutrient concentrations, the densities of both diatoms and

267 other algal groups have increased. This was similar to the observation reported earlier

268 by Yung et al. (1997) that there was an increase in the density of phytoplankton,

269 especially that of other algal groups, when chlorophyll- $a$ concentrations had not

270 increased. As other algal groups in both Yung et al. (1997) and this study included

271 mainly unidentified small flagellates and cryptomonads, an increase in the abundance

272 of these small organisms may not be accompanied by an increase of chlorophyll- $a$

273 concentrations. This is somewhat supported by the fact that correlation between

274 density of other algal group and chlorophyll- $a$ concentrations was recorded only at

275 TM8, while diatoms and dinoflagellates correlated strongly and positively with

276 chlorophyll- $a$ concentrations at all stations.

277 Water quality measured in terms of nutrients and chlorophyll- $a$ concentration has

278 always been better in the channel region than in the inner part of the harbour (Hu et al., 
279 2001; Lam and Ho, 1989; Yung et al., 1997), and a seaward decrease in nutrient

280 concentrations from the inner harbour to the channel was evident from our results. A

281 similar spatial pattern, with water quality improving from TM3 to TM8, is recorded in

282 other water quality indicators such as secchi depth, DO and $\mathrm{BOD}_{5}$. Due to its

283 proximity to the open sea and the much lower pollution levels, TM8 was less affected

284 by eutrophication and subsequent declines in nutrient concentrations compared to

285 stations in the inner part of the harbour. An interesting observation was that the mean

286 values of $\mathrm{NO}_{3} / \mathrm{NH}_{4}$ decreased at TM3, TM4 and TM6, but increased at TM8 after

287 declines in nutrient concentrations. This may be caused by a relatively higher decline

288 of $\mathrm{NH}_{4}-\mathrm{N}$ concentrations than that of $\mathrm{NO}_{3}-\mathrm{N}$ in TM8. The maximum release rate of

$289 \mathrm{NH}_{4}-\mathrm{N}$ from contaminated sediments into the water column in Tolo Harbour was

290 found to be more than sixfolds higher than that of $\mathrm{NO}_{3}-\mathrm{N}$ (Hu et al. 2001), and

291 although $\mathrm{Hu}$ et al. (2001) did not specify specific nutrient release rates in various parts

292 of Tolo Harbour, it may be possible that comparatively less $\mathrm{NH}_{4}-\mathrm{N}$ was released back

293 into the water column from sediments in the less polluted outer parts of the Tolo

294 Harbour.

295 Spatial differences in nutrient loading and tidal flushing may have led to the

296 observed differences in how phytoplankton in different stations had responded to

297 declines in nutrient concentrations. Correlation between phytoplankton densities and 
298 314 dinoflagellate density has been detected in our data, despite a significant increase in $315 \mathrm{TIN} / \mathrm{PO}_{4}$ after declines in nutrient concentrations. In general, the density of 316 dinoflagellates correlate neither with $\mathrm{TIN} / \mathrm{PO}_{4}$ nor with most physico-chemical

nutrient concentrations was poor and usually insignificant at TM6 and TM8 in the outer part of the harbour. In contrast, phytoplankton densities at TM3 and TM4 tended to correlate strongly and negatively with nutrient concentrations, suggesting that nutrients were removed rapidly by phytoplankton in the inner part of Tolo Harbour.

\subsection{Changes in nutrient ratios and shifts in the phytoplankton community}

1990), a decrease in $\mathrm{NO}_{3} / \mathrm{NH}_{4}$ may favor phytoplankton growth. However, the lack of consistent correlation between $\mathrm{NO}_{3} / \mathrm{NH}_{4}$ and phytoplankton density suggests that the phytoplankton community in Tolo Harbour did not have specific preference for either $\mathrm{NO}_{3}$ or $\mathrm{NH}_{4}$.

Decreases in nutrient concentrations following nutrient loading reduction measures had altered the values of $\mathrm{TIN} / \mathrm{PO}_{4}$ and $\mathrm{TIN} / \mathrm{SiO}_{2}$ significantly. Hodgkiss and Ho (1997) related the increased abundance of dinoflagellates in Tolo Harbour to a decrease in $\mathrm{N}: \mathrm{P}$ ratios. It must be noted that no evidence of a decrease in 
317 parameters other than Secchi depth and $\mathrm{BOD}_{5}$, both of which may be dependent

318 variables affected by the dinoflagellate density. Hence, the density of dinoflagellate in

319 Tolo Harbour may not be easily predicted from nutrient concentrations or N:P ratios

320 alone. While our analysis has not established a strong link between nutrient

321 concentrations and dinoflagellate densities, several investigators have reported an

322 increasing dominance of dinoflagellates during the 1980s and early 1990s when

323 nutrient concentrations in Tolo Harbour were at their highest (Chan and Hodkiss,

324 1987; Hodgkiss and Chan, 1983; Hodgkiss and Ho, 1997; Lam and Ho, 1989). The

325 density of dinoflagellates was at a peak in 1996 when TIN/PO 4 was very low (Figs. 3

$326 \& 4)$. The density of dinoflagellates reached another peak in 1998 , due primarily to an

327 extremely dense population of Prorocentrum (122,467 cells ml $\left.{ }^{-1}\right)$ at TM3 in April.

328 But dinoflagellate densities have remained relatively low since 2005 , while TIN/PO

329 increased. Hodgkiss and Ho (1997) also noted a decrease in N:P ratios and an increase

330 in algal blooms from 1981-1990. Our data showed no significant correlation between

331 these two variables, although an increase in $\mathrm{TIN} / \mathrm{PO}_{4}$ and a decrease in the number of

332 algal blooms were found after declines in nutrient concentrations. Nevertheless, while

333 our data did not contain information about Noctiluca blooms, Liu and Wong (2006)

334 showed that Noctiluca scintillans were still common in Tolo Harbour after declines in

335 nutrient concentrations, and Noctiluca blooms still persisted. 
$338 \mathrm{SiO}_{2}$ concentrations was recorded after declines in nutrient input $(p=0.045)$, surface

$339 \mathrm{SiO}_{2}$ concentrations did not changed significantly $(p=0.849)$. Overall, $\mathrm{TIN} / \mathrm{SiO}_{2}$

340 tended to decrease at all sampling stations. Diatoms have a physiological N:Si ratio of

341 1:1 (Turner, 2002), and an environmental ratio of $>1$ has been reported to limit

342 diatom growth and shift a diatom-dominated community to one dominated by

343 non-diatoms, particularly flagellates (Cloern, 2001; Egge and Aksnes, 1992; Paul et

344 al., 2008; Turner et al. 1998). While diatom densities did correlate weakly with

$345 \mathrm{TIN} / \mathrm{SiO}_{2}$ in $\mathrm{TM} 3$ and $\mathrm{TM} 4$, diatoms were the most abundant algal group in these two

346 stations and Tolo Harbour (Lam and Ho, 1989; Yung et al., 1997) before declines in

347 nutrient concentrations, when $\mathrm{TIN} / \mathrm{SiO}_{2}$ at $\mathrm{TM} 3$ and $\mathrm{TM} 4$ were frequently $>1$. This

348 suggests that although $\mathrm{N}: \mathrm{Si}$ ratios may have some effect on diatom densities, it is not

349 enough to shift diatom dominance in Tolo Harbour. In addition, the Si concentrations

350 in Tolo Harbour may not be limiting to diatom growth. Egge and Aksnes (1992)

351 reported that a $\mathrm{Si}$ concentration of $>2 \mu \mathrm{M}$ was enough to induce consistent

352 dominance by diatoms in Norway. While this low threshold concentration may not

353 apply in the warm subtropical waters of Hong Kong, the lowest $\mathrm{SiO}_{2}$ concentration in

354 this study was $\sim 10 \mu \mathrm{M}$ at TM8, fivefolds higher than the threshold concentration 
355 reported in Norway, and may be sufficient to support diatom growth regardless of

$356 \mathrm{TIN} / \mathrm{SiO}_{2}$. It should be noted that the maintenance of dominance by diatoms may not

357 necessarily be beneficial both ecologically and economically. Although centric

358 diatoms have been suggested to be the more desirable phytoplankton group when

359 compared to non-diatom groups, such as dinoflagellates, due to their higher nutritional

360 value and low toxicity (Hecky and Kilham, 1988; Officer and Ryther, 1980), pennate

361 diatoms, including those belonging to the genus Pseudo-nitzschia, are also common in

362 Tolo Harbour (Lam and Ho, 1989). Some species of Pseudo-nitzschia have been

363 known to release the toxin domoic acid (Lefebvre et al., 2002; Sekula-Wood et al.,

364 2009), and a connection between Pseudo-nitzschia blooms and eutrophication has

365 been proposed (Parsons and Dortch, 2002; Schnetzer et al., 2007). Fortunately,

366 Pseudo-nitzschia spp. may prefer high nitrate waters (Paul et al., 2008; Carter et al.,

367 2005), so declines in nutrient concentrations in Tolo Harbour should discourage

368 Pseudo-nitzschia blooms.

369 Although our data does not contain information on the size structure of the

370 phytoplankton community, changes in nutrient concentration or ratios may cause a

371 shift from larger phytoplankton species or cells to smaller ones. Stolte and Riegman

372 (1995) had theorized that eutrophication favors large phytoplankton species because

373 their larger storage capacity allows them to better compete under high nutrient 
374 concentrations. Indeed, a shift towards an eutrophic environment has been shown to

375 favor large diatoms in the western Wadden Sea (Stolte el al., 1994; Philippart et al.,

376 2000), and Qiu et al. (2010) reported strong negative correlations between $\leq 3 \mu \mathrm{m}$

377 chlorophyll- $a$ and nutrient concentrations. The half-saturation constant for P uptake

378 has been reported to be as high as $4.85-6.67 \mu \mathrm{M}$ at $20^{\circ} \mathrm{C}$ for certain large diatom

379 species (Nishikawa et al. 2009 and 2010), much higher than the means of TP in Tolo

380 Harbour after nutrient loading reduction (Table 2). Declines in nutrient concentrations

381 in Tolo Harbour may therefore favor smaller cells and species that are more

382 competitive in a less eutrophic condition. Qiu et al. (2010) reported significant

383 positive correlation between $<20 \mu \mathrm{m}$ chlorophyll $a$ concentrations and N/P ratios.

384 Our data also show a strong and positive correlation between $\mathrm{TIN} / \mathrm{PO}_{4}$ and other algal

385 group densities, caused mainly by an increase in the density of small flagellates and

386 Cryptomonas. Recent studies in Tolo Harbour have revealed that cells $<5 \mu \mathrm{m}$

387 accounted for $>25 \%$ of the chlorophyll- $a$ biomass (Lie and Wong, 2010; Wong et al.,

388 2010). In addition, phytoplankton size structures in many aquatic ecosystems have

389 also been known to be affected by climate change, particularly by increases in water

390 column stratification due to increased temperature (Finkel, 2007; Smol et al., 2005;

391 Winder et al., 2010). If indeed such a shift to smaller phytoplankton is occurring in

392 Tolo Harbour, it would help to explain the increase in phytoplankton density as 
393 chlorophyll- $a$ concentrations decrease.

398 freshwater lakes (e.g. Jeppesen et al., 2002; Jeppesen et al., 2005; Søndergaard et al., 399 2002), and most have reported improvements in water quality. Water quality 400 improvement is mainly achieved through the decrease in phytoplankton biomass. This 401 decrease can occur as a direct response to declines in nutrient concentrations, but it 402 can be further facilitated through increased grazing pressure from zooplankton grazers 403 (Edmondson, 1994) and the recolonization of submerged macrophytes, which has 404 been shown to substantially affect the success rates of water quality improvement in 405 lakes (Mehner et al., 2002). While there may be differences between freshwater and 406 marine systems in their responses to declines in nutrient concentrations (Cloern, 2001;

407 Smith et al., 1999), examples of dramatic improvements in once eutrophicated marine 408 ecosystems such as Hillsborough Bay, Florida (Johansson and Lewis, 1992) and the 409 coastal waters of Denmark (Rask et al., 1999) had both involved the recolonization of 410 macrophytes such as seagrasses (Hillsborough Bay) and eelgrass (Denmark). 411 However, an early study in Tolo Harbour has shown that most of the harbour was 
412 covered by extremely fine sediments that support little plant life (Trott, 1972).

413 Therefore, even with the decline of nutrient concentrations and increase in water

414 transparency, the spread of macrophytes in Tolo Harbour is unlikely.

415 In regards to the zooplankton grazers in Tolo Harbour, a study comparing the

416 copepod community before and after declines in nutrient concentrations in Tolo

417 Harbour revealed a decrease in copepod density, from 6,392 ind. $\mathrm{m}^{-3}$ in $1987-1991$, to

418 4,810 ind. $\mathrm{m}^{-3}$ in 2003-2004 (Wong et al., 1993; Zhang and Wong, submitted). The

419 mesozooplankton community in Tolo Harbour was found to be heavily preyed upon

420 by larval and juvenile stages of the black seabream, Acanthopagrus schlegeli, and the

421 Japanese seaperch, Lateolabrax japonicus, which use Tolo Harbour as a nursery

422 habitat (Nip et al. 2003). While presently there is no detailed description on the fish

423 population in Tolo Harbour, the abundance of small planktivorous fishes will most

424 likely increase when increased fishing pressure from overfishing of larger piscivorous

425 fishes reduces the predation pressure on the small fishes. Such changes will in turn

426 increase the predation pressure on mesozooplankton grazers, reducing their

427 abundance and delaying any further decrease of phytoplankton abundance.

428 Although every water mass may have different responses to declines in nutrient

429 concentrations (Carvalho et al., 1995; Smith et al., 1999), it is obvious that trophic

430 interactions play a significant role in determining the outcome (Carpenter et al., 1995, 
431 Manca and Ruggiu, 1998; Proulex et al., 1996; Smith et al., 1999). Increase in

432 macrophytes and zooplankton grazers can further facilitate the decrease in

433 phytoplankton biomass (Edmondson, 1994; Mehner et al., 2002), but the presence of

434 planktivores and piscivores can affect the abundance of zooplankton grazers.

435 Therefore, an appropriate balance between piscivores, planktivores and zooplankton

436 grazers should be maintained to ensure the long-term stability of the recovered

437 ecosystem (Mehner et al. 2002). Unfortunately, there is a lack of long-term

438 monitoring on other communities, such as zooplankton and nekton, in Tolo Harbour.

439 As there is insufficient information on the responses of various communities to

440 changes in nutrient loading, the phytoplankton community alone is not a reliable

441 indicator of the trophic status of the whole ecosystem (Philippart et al. 2007). Future

442 efforts in water quality monitoring and eutrophic coastal restoration should therefore

443 focus not only on nutrient concentrations and phytoplankton biomass and densities,

444 but also other important components of the aquatic ecosystem such as zooplankton

445 and nekton communities.

\section{Acknowledgements}

448 The authors would like to express their thanks to the staff of the Hong Kong

449 Environmental Protection Department and the Government Chemists for collecting 
450 and analyzing the samples. We are also grateful to the Director of Environmental

451 Protection for his permission to use the data. The opinions in this paper are those of

452 the authors and do not necessarily reflect the views or policies of the Hong Kong

453 Government. Suggestions and comments given by two anonymous reviewers are 454 greatly appreciated.

455

456 References

457

458 American Public Health Association, American Water Works Association, Water

459 Environment Federation, 1998. Standard methods for the examination of water

460 and wastewater, $20^{\text {th }}$ Edition. American Public Health Association, Washington

$461 \quad$ DC.

462 Anderson, D.M., Burkholder, J.M., Cochlan, W.P., Glibert, P.M., Gobler, C.J., Heil,

463 C.A., Kudela, R.M., Parsons, M.L., Rensel, J.E.J., Townsend, D.W., Trainer,

464 V.L., Vargo, G.A., 2008. Harmful algal blooms and eutrophication: Examining

465 linkages from selected coastal regions of the United States. Harmful Algae 8, $466 \quad 39-53$.

467 Battarbee, R.W., Anderson, N.J., Jeppesen, E., Leavitt, P.R., 2005. Combining 468 palaeolimnological and limnological approaches in assessing lake ecosystem 
Carpenter, S.R., Christensen, D.L., Cole, J.J., Cottingham, K.L., He, X., Hodgson, J.R., Kitchell, J.F., Knight, S.E., Pace, M.L., Post, D.M., Schindler, D.E., Voichick, N., 1995. Biological control of eutrophication. Envrionmental Science and Technology 29, 784-786.

Carpenter, S.R., Ludwig, D., Brock, W.A., 1999. Management of eutrophication for lakes subject to potentially irreversible change. Ecological Applications 9, 751-771.

Carter, C.M., Ross, A.H., Schiel, D.R., Howard-Williams, C., Hayden, B., 2005. In situ microcosm experiments on the influence of nitrate and light on phytoplankton community composition. Journal of Experimental Marine Biology and Ecology 326, 1-13.

Carvalho, L., Beklioglu, M., Moss, B., 1995. Changes in a deep lake following sewage diversion - a challenge to the orthodoxy of external phosphorus control as a restoration strategy? Freshwater Biology 34, 399-410. climate change and nutrient reduction. Hydrobiologia 506-509, 789-796. 
488

490

491

492

494

500

Chau, Y.K., Abesser, R.A., 1958. A preliminary study of the hydrology of Hong Kong Territorial Waters. Hong Kong University Fisheries Journal 2, 43-58.

Cloern, J.E., 2001. Our evolving conceptual model of the coastal eutrophication problem. Marine Ecology Progress Series 210, 223-253.

de Benardi, R., Calderoni, A., Mosello, R., 1996. Environmental problems in Italian lakes, and lakes Maggiore and Orta as successful examples of correct management leading to restoration. Verhandlungen deer Internationale Vereinigung fur Theorestische undo Angewandte Limnologie 26, 123-138.

Dortch, Q., 1990. The interaction between ammonium and nitrate uptake in phytoplankton. Marine Ecology Progress Series 61, 183-201.

Edmondson, W.T., 1994. Sixty years of Lake Washington: a curriculum vitae. Lake Reservoir Management 10, 75-84.

Egge, J.K., Aksnes, D.L., 1992. Silicate as regulating nutrient in phytoplankton competition. Marine Ecology Progress Series 83, 281-289.

Finkel, Z.V., 2007. Does size matter? The evolution of modern marine food webs. In: Falkowski, P.G., Knoll, A.H. (Eds.), The evolution of aquatic photoautotrophs. Academic Press, New York. Pp. 333-350.

Hansen, P.J., Miranda, L., Azanza, R., 2004. Green Noctiluca scintillans: a 

79-87.

Hecky, R.E., Kilham, P., 1988. Nutrient limitation of phytoplankton in freshwater and marine environments: A review of recent evidence on the effects of enrichment. Limnology \& Oceanography 33, 796-822.

Hodgkiss, I.J., Chan, B.S.S., 1983. Pollution studies in Tolo Harbour, Hong Kong. Marine Environmental Research 10, 1-44.

Hodgkiss, I.J., Ho, K.C., 1997. Are changes in N:P ratios in coastal waters the key to increased red tide blooms? Hydrobiologia 352, 141-147.

Hodgkiss, I.J., Yim, W.W., 1995. A case study of Tolo Harbour, Hong Kong. In: McComb, A.J. (Ed.) Eutrophic shallow estuaries and lagoons. CRC Press, Florida. Pp. 41-57.

Hong Kong Environmental Protection Department, 2009. Marine Water Quality in Region, Hong Kong.

521 Hong Kong Environmental Protection Department, 1991. Marine Water Quality in Hong Kong in 1990. The Government of the Hong Kong Special Administrative Region, Hong Kong. 
524 Hu, W.F., Lo, W., Chua, H., Sin, S.N., Yu, P.H.F., 2001. Nutrient release and sediment oxygen demand in a eutrophic land-locked embayment in Hong Kong. Environment International 26, 369-375.

527

528

Jeppesen, E., Jensen, J.P., Søndergaard, M., 2002. Response of phytoplankton, zooplankton and fish to re-oligotrophication: an 11-year study of 23 Danish lakes. Aquatic Ecosystem Health and Management 5, 31-43.

Jeppesen, E., Meerhoff, M., Jacobsen, B.A., Hansen, R.S., Søndergaard, M., Jensen, J.P., Lauridsen, T.L., Mazzeo, N., Branco, C.W.C., 2007. Restoration of shallow lakes by nutrient control and biomanipulatioin - the successful strategy varies with lake size and climate. Hydrobiologia 581, 269-285.

Jeppesen, E., Søndergaard, M., Jensen, J.P., Havens, K.E., Anneville, O., Carvalho, L., Coveney, M.F., Deneke, R., Dokulil, M.T., Foy, B., Gerdeaux, D., Hampton, S.E., Hilt, S., Kangur, K., Köhler, J., Lammens, E.H.H.R., Lauridsen, T.L., Manca, M., Miracle, M.R., Moss, B., Nõges, P., Persson, G., Phillips, G., Portielje, R., Romo, S., Schelske, C.L., Straile, D., Tatrai, I., Willén, E. \& Winder, M., 2005. Lake responses to reduced nutrient loading - an analysis of contemporary long-term data from 35 case studies. Freshwater Biology 50, 1747-1771.

Johansson, J.O.R., Lewis, R.R., 1992. Recent improvements in water quality and 
543

544

545

biological indicators in Hillsborough Bay, a highly impacted subdivision of Tampa Bay, Florida, USA. In: Volenweider, R.A., Marchetti, R., Viviani, R. (Eds.), Marine coastal eutrophication. The response of marine transitional systems to human impact: Problems and perspectives for restoration. Science of the total environment supplement 1992. Elsevier Science, Amsterdam. Pp. 1199-1216.

Justić, D., Rabalais, N.N., Turner, R.E., 1995. Stoichiometric nutrient balance and origin of coastal eutrophication. Marine Pollution Bulletin 30, 41-46.

Kiørboe, T., Titelman, J., 1998. Feeding, prey selection and prey encounter meachanisms in the heterotrophic dinoflagellate Noctiluca scintillans. Journal of Plankton Research 20, 1615-1636.

Lam, C.W.Y., Ho, K.C., 1989. Phytoplankton characteristics of Tolo Harbour. Asian Marine Biology 6, 5-18.

Lee, J.H.W., Harrison, P.J., Kuang, C., Yin, K., 2006. Eutrophication dynamics in Hong kong Coastal Waters: Physical and Biological Interactions. In Wolanski, E. (Ed.), Environment in Asia Pacific Harbours. Springer, the Netherlands. Pp. 187-206.

Lefebvre, K.A., Silver, M.W., Coale, S.L., Tjeerdema, R.S., 2002. Domoic acid in planktivorous fish in relation to toxic Pseudo-nitzschia cell densities. Marine 
Biology 140, 625-631.

563 Lie, A.A.Y., Wong, C.K. 2010. Selectivity and grazing impact of

564

565

566

567

568

569

570 microzooplankton on phytoplankton in two subtropical semi-enclosed bays with different chlorophyll concentrations. Journal of Experimental Marine Biology and Ecology, in press.

Liu, X., Wong, C.K., 2006. Seasonal and spatial dynamics of Noctiluca scintillans in a semi-enclosed bay in the northeastern part of Hong Kong. Botanica Marina 49, 145-150.

Manca, M., Ruggiu, D., 1998. Consequences of pelagic food-web changes during a long-term lake oligotrophication process. Limnology \& Oceanography 43, $1368-1373$.

Mehner, T., Benndorf, J., Kasprazak, P., Koschel, R., 2002. Biomanipulation of lake ecosystems: successful applications and expanding complexity in the underlying science. Freshwater Biology 47, 2453-5465.

Mehner, T., Kasprzak, P., Wysujack, K., Laude, U., Koschel, R., 2001. Restoration of a stratified lake (Feldberger Haussee, Germany) by a combination of nutrient load reduction and long-term biomanipulation. Internation Review of Hydrobiology 2, 253-265.

Nip, T.H.M., Ho, W., Wong, C.K., 2003. Feeding ecology of larval and juvenile black 
583 Nishikawa, T., Tarutani, K., Yamamoto, T., 2009. Nitrate and phosphate uptake kinetics of the harmful diatom Eucampia zodiacus Ehrenberg, a causative organism in the bleaching of aquacultured Porphyra thalli. Harmful Algae 8, 513-517.

Nishikawa, T., Tarutani, K., Yamamoto, T., 2010. Nitrate and phosphate uptake kinetics of harmful diatom Coscinodiscus wailesii, a causative organism in the bleaching of aquacultured Porphyra thalli. Harmful Algae 9, 563-567.

Nixon, S. W., 1995. Coastal marine eutrophication: A definition, social causes, and future concerns. Ophelia 41, 199-219.

Officer, C.B., Ryther, J.H., 1980. The possible importance of silicon in marine eutrophication. Marine Ecology Progress Series 3, 83-91.

Parsons, M.L., Dortch, Q., 2002. Sedimentological evidence of an increase in Pseudo-nitzschia (Bacillariophyceae) abundance in response to coastal eutrophication. Limnology \& Oceanography 47, 551-558. 
600 Philippart, C.J.M., Beukema, J.J., Cadée, G.C., Dekker, R., Goedhart, P.W., van Iperen,

601 J.M., Leopold, M.F., Herman, P.M.J., 2007. Impacts of nutrient reduction on 602 coastal communities. Ecosystems 10, 95-118.

603 Philippart, C.J.M., Cadée, G.C., van Raaphorst, W., Riegman, R., 2000. Long-term 604

605 phytoplankton-nutrient budgets, and denitrification potential. Limnology \& Oceanography 45, 131-144.

606

Proulx, M., Pick, F.R., Mazumder, A., Hamilton, P.B., Lean, D.R.S., 1996. Effects of 607 nutrients and planktivorous fish on the phytoplankton of shallow and deep 608

609 aquatic ecosystems. Canadian Journal of Fisheries and Aquatic Sciences 77,

610 Qiu, D., Huang, L., Zhang, J., Lin, S., 2010. Phytoplankton dynamics in and near the highly eutrophic Pearl River Estuary, South China Sea. Continental Shelf

613 Rask, N., Pedersen, S.T., Jensen, M.H., 1999. Response to lowered nutrient discharges

614 in the coastal waters around the island of Funen, Denmark. Hydrobiologia 363, 615 $69-81$.

616 Reckhow, K.H., Chapra, S.C., 1999. Presistent organic pollutants (POPs): State of the 617 science. Environmental Pollution 100, 209-221.

618 Sekula-Wood, E., Schnetzer, A., Benitez-Nelson, C.R., Anderson, C., Berelson, W.M., 
619

Brzezinski, M.A., Burns, J.M., Caron, D.A., Cetinic, I., Ferry, J.L., Fitzpatrick, E., Jones, B.H., Miller, P.E., Morton, S.L., R.A., Siegel, D.A., Thunell, R., 2009. Rapid downward transport of the neurotoxin domoic acid in caostal waters. Nature Geoscience 2, 272-275.

Schnetzer, A., Miller, P.E., Schaffner, R.A., Stauffer, B.A., Jones, B.H., Weisberg, S.B., DiGiacomo, P.M., Berelson, W.M., Caron, D., 2007. Blooms of Psuedo-nitzschia and domoic acid in the San Pedro Channel and Los Angeles harbor areas of the Southern California Bight, 2003-2004. Harmful Algae 6, 372-387.

Smith, V.H., 1983. Low nitrogen to phosphorus ratios favor dominance by blue-green algae in lake phytoplankton. Science 221, 669-671.

Smith, V.H., 1998. Cultural eutrophication of inland, estuarine, and coastal waters. In: Pace, M.L., Groffman, P.M. (Eds.) Successes, limitations and frontiers in ecosystem science. Springer, New York. Pp. 7-49.

Smith, V.H., 2003. Eutrophication of freshwater and coastal marine ecosystems. A global problem. Environmental Science and Pollution Research 10,126-139.

Smith, V.H., Tilman, G.D., Nekola, J.C. 1999. Eutrophication: impacts of excess nutrient inputs on freshwater, marine, and terrestrial ecosystems. Environmental Pollution 100, 179-196. 
638 Smol, J.P., Wolfe, A.P., Birks, H.J.B., Douglas, M.S.V., Jones, V.J., Korhola, A., Pientzl, R., Rühland, K., Sorvari, S., Antoniades, D., Brooks, S.J., Fallu, M.A.,

640 Hughes, M., Keatley, B.E., Laing, T.E., Michelutti, N., Nazarova, L., Nyman, M., Paterson, A.M., Perren, B., Quinlan, R., Rautio, M., Saulnier-Talbot, E., Siltonene, S., Solovieva, N., Weckström, J., 2005. Climate-drive regime shifts in

Søndergaard, M., Jensen, J.P., Jeppesen, E., Moller, P.H., 2002. Seasonal dynamics in 646 the biological communities of arctic lakes. Proceedings of the National Academy of Sciences 102, 4397-4402. the concentrations and retention of phosphorus in shallow Danish lakes after reduced loading. Aquatic Ecosystem Health and Management 5, 19-23.

Sriwoon, R., Pholpunthin, P., Lirdwitayaprasit, T., Kishino, Furuya, K., 2008. Population dynamics of green Noctiluca scintillans (Dinophyceae) associated with the monsoon cycle in the upper gulf of Thailand. Journal of Phycology 44, $605-615$.

Stolte, W., McCollin, T., Noordeloos, A.A.M., Riegman, R., 1994. Effect of nitrogen source on the size distribution within marine phytoplankton populations. Journal of Experimental Marine Biology and Ecology 184, 83-97. 
657 Sweeney, B.M., 1971. Laboratory studies of a green Noctiluca from New Guinea.

658 Journal of Phycology 7, 53-58.

659

Trott, L.B., 1972. Marine ecology in Tolo Harbour, Hogn Kong. Chung Chi Journal 11,

660 26-32.

661 Turner, R.E., 2002. Element ratios and aquatic food webs. Estuaries 25, 694-703.

662 Turner, R.E, Qureshi, N., Rabalais, N.N., Dortch, Q., Justić, D., Shaw, R.F., Cope, J., 663 1998. Fluctuating silicate:nitrate ratios and coastal plankton food webs. Proceedings of the National Academy of Sciences 95, 13048-13051.

665

666

667

668

669

670

671

672

673

674

Wear, R.G., Thompson, G.B., Stirling, H.P., 1984. Hydrography, nutrients and plankton in Tolo Harbour, Hong Kong. Asian Marine Biology 1, 59-75.

Winder, M., Reuter, J.E., Schladow, S.G., 2009. Lake warming favors small-sized planktonic diatom species. Proceedings of the Royal Society B 276, 427-435.

Wong, C.K., Chan , A.L.C., Chen, Q.C., 1993. Planktonic copepods of Tolo Harbour, Hong Kong. Crustaceana 64, 76-84.

Wong, C.K., Tang, C.C.H., Lie, A.A.Y., Lam, J.Y.C., Yung, Y.K. 2010. Size structure and taxonomic composition of phytoplankton in Hong Kong waters. In: Tow, T.T., Yusup, Y., Fizri, F.F.A. (Eds.) Proceedings International Conference on Environmental Research and Technology (ICERT 2010). Universiti Sains Malaysia, Malaysia. Pp. 560-564. 
676 Wu, R.S.S., 1988. Marine pollution in Hong kong: a review. Asian Marine Biology $5: 1-23$.

678

Yung, Y.K., Wong, C.K., Broom, M.J., Ogden, J.A., Chan, S.C.M., Leung, Y., 1997.

679 Long-term changes in hydrography, nutrients and phytoplankton in Tolo 680 Harbour, Hong Kong. Hydrobiologia 352, 107-115.

681

Zhang, G., Wong, C.K. Changes in the planktonic copepod community in a landlocked eutrophication. Hydrobiologia submitted.

684

685

\section{Figure Legends}

686 Fig. 1. A map of Hong Kong and Tolo Harbour showing the location of the four 687 sampling stations.

688

689 Fig. 2. Temporal variations in the annual means of total inorganic nitrogen, total

690 nitrogen, total phosphorus and $\mathrm{SiO}_{2}$ concentration at the four sampling stations from

691 1986-2008. The shaded area represents the period before nutrient loading reduction .

692

693 Fig. 3. Temporal variations in the annual means of $\mathrm{NO}_{3} / \mathrm{NH}_{4}, \mathrm{TIN} / \mathrm{PO}_{4}$ and $\mathrm{TIN} / \mathrm{SiO}_{2}$

694 at the four sampling stations from 1986-2008. The shaded area represents the period 
695 before nutrient loading reduction. The dashed lines indicate the Redfield N:P and N:Si

696 ratios of $16: 1$ and 1:1 respectively.

697

698 Fig. 4. Temporal variations in the annual means of chlorophyll $a$ at the four sampling

699 stations from 1986-2008. The shaded area represents the period before nutrient

700 loading reduction.

701

702 Fig. 5. Temporal variations in the annual means of diatoms, dinoflagllates, other algal

703 groups and total phytoplankton densities at the four sampling stations from

704 1986-2008. The shaded area represents the period before nutrient loading reduction.

705 Monitoring began in 1988 for TM3 and TM4, 1994 for TM6 and 1986 for TM8. 
Research highlights

Our study investigates the long-term changes in physico-chemical parameters, including nutrient concentration, nutrient ratios, and phytoplankton before and after nutrient reduction in an eutrophic bay in Hong Kong. Such study with long-term data relating environmental factors and phytoplankton is rather uncommon in marine ecosystems. We believe that such study of how anthropogenic causes led to changes in the phytoplankton community fits the aims and scope of your journal. 
Table 1. Mean values ( \pm standard deviation) of various physico-chemical, biological and nutrient ratios. "All stations" refers to the mean of all four sampling stations. "86-97" indicates the period before nutrient loading reduction (i.e. 1986-1997), and "98-08" indicates the period after nutrient loading reduction (i.e. 1998-2008). "Overall" refers to the entire study period of 1986-2008. Values are depth-averaged values except for "Bottom DO" and "Bottom $\mathrm{BOD}_{5}$ ".

\begin{tabular}{|c|c|c|c|c|c|c|}
\hline \multirow{2}{*}{ Parameter } & & \multicolumn{5}{|c|}{ Station } \\
\hline & & TM3 & TM4 & TM6 & TM8 & All stations \\
\hline \multirow{3}{*}{ Temperature $\left({ }^{\circ} \mathrm{C}\right)$} & $86-97$ & $23.06 \pm 4.33$ & $22.88 \pm 4.32$ & $22.55 \pm 4.14$ & $22.20 \pm 4.02$ & $22.67 \pm 4.19$ \\
\hline & $98-08$ & $23.93 \pm 4.13$ & $23.68 \pm 4.13$ & $23.36 \pm 4.01$ & $22.92 \pm 3.87$ & $23.47 \pm 4.02$ \\
\hline & Overall & $23.47 \pm 4.25$ & $23.26 \pm 4.24$ & $22.93 \pm 4.09$ & $22.55 \pm 3.96$ & $23.06 \pm 4.12$ \\
\hline \multirow{3}{*}{$\mathrm{pH}$} & $86-97$ & $8.31 \pm 0.20$ & $8.29 \pm 0.23$ & $8.26 \pm 0.19$ & $8.24 \pm 0.17$ & $8.27 \pm 0.18$ \\
\hline & $98-08$ & $8.21 \pm 0.20$ & $8.16 \pm 0.21$ & $8.16 \pm 0.20$ & $8.16 \pm 0.15$ & $8.17 \pm 0.17$ \\
\hline & Overall & $8.26 \pm 0.20$ & $8.23 \pm 0.23$ & $8.21 \pm 0.20$ & $8.20 \pm 0.17$ & $8.22 \pm 0.19$ \\
\hline \multirow{3}{*}{ Salinity } & $86-97$ & $30.75 \pm 1.55$ & $30.77 \pm 1.66$ & $31.44 \pm 1.51$ & $31.96 \pm 1.06$ & $31.22 \pm 1.39$ \\
\hline & $98-08$ & $31.18 \pm 1.56$ & $31.29 \pm 1.48$ & $31.78 \pm 1.21$ & $32.31 \pm 1.07$ & $31.64 \pm 1.28$ \\
\hline & Overall & $30.96 \pm 1.57$ & $31.02 \pm 1.60$ & $31.61 \pm 1.38$ & $32.13 \pm 1.08$ & $31.42 \pm 1.35$ \\
\hline \multirow{3}{*}{$\mathrm{DO}\left(\mathrm{mg} \mathrm{l}^{-1}\right)$} & $86-97$ & $6.86 \pm 1.93$ & $6.85 \pm 1.86$ & $6.45 \pm 1.61$ & $6.36 \pm 1.65$ & $6.63 \pm 1.60$ \\
\hline & $98-08$ & $6.98 \pm 1.37$ & $6.70 \pm 1.33$ & $6.26 \pm 1.33$ & $6.06 \pm 1.34$ & $6.50 \pm 1.22$ \\
\hline & Overall & $6.92 \pm 1.68$ & $6.78 \pm 1.62$ & $6.36 \pm 1.48$ & $6.22 \pm 1.51$ & $6.57 \pm 1.43$ \\
\hline \multirow{3}{*}{ Bottom DO $\left(\mathrm{mg} \mathrm{l}^{-1}\right)$} & $86-97$ & $4.97 \pm 2.44$ & $4.78 \pm 2.42$ & $4.83 \pm 2.34$ & $5.10 \pm 2.56$ & $4.92 \pm 2.18$ \\
\hline & $98-08$ & $6.30 \pm 1.86$ & $5.86 \pm 1.88$ & $5.30 \pm 1.92$ & $5.19 \pm 2.02$ & $5.66 \pm 1.73$ \\
\hline & Overall & $5.61 \pm 2.28$ & $5.29 \pm 2.24$ & $5.05 \pm 2.16$ & $5.15 \pm 2.31$ & $5.28 \pm 2.01$ \\
\hline \multirow{3}{*}{$\begin{array}{c}\mathrm{BOD}_{5} \\
\left(\mathrm{mg} \mathrm{l}^{-1}\right)\end{array}$} & $86-97$ & $2.55 \pm 0.99$ & $2.44 \pm 0.89$ & $1.81 \pm 0.72$ & $1.18 \pm 0.60$ & $2.00 \pm 0.65$ \\
\hline & $98-08$ & $1.98 \pm 0.75$ & $1.73 \pm 0.56$ & $1.38 \pm 0.47$ & $0.89 \pm 0.56$ & $1.49 \pm 0.45$ \\
\hline & Overall & $2.28 \pm 0.93$ & $2.10 \pm 0.83$ & $1.60 \pm 0.65$ & $1.04 \pm 0.60$ & $1.76 \pm 0.62$ \\
\hline \multirow{3}{*}{$\begin{array}{l}\text { Bottom BOD } \\
\quad\left(\mathrm{mg} \mathrm{l}^{-1}\right)\end{array}$} & 86-97 & $1.33 \pm 0.65$ & $1.38 \pm 0.79$ & $0.95 \pm 0.56$ & $0.71 \pm 0.40$ & $1.09 \pm 0.50$ \\
\hline & $98-08$ & $1.35 \pm 0.66$ & $1.24 \pm 0.60$ & $0.89 \pm 0.56$ & $0.56 \pm 0.42$ & $1.01 \pm 0.41$ \\
\hline & Overall & $1.34 \pm 0.66$ & $1.32 \pm 0.71$ & $0.92 \pm 0.56$ & $0.63 \pm 0.42$ & $1.05 \pm 0.46$ \\
\hline
\end{tabular}




\begin{tabular}{|c|c|c|c|c|c|c|}
\hline \multirow{3}{*}{ Secchi Depth (m) } & $86-97$ & $1.83 \pm 0.66$ & $1.82 \pm 0.67$ & $2.23 \pm 0.79$ & $3.49 \pm 1.39$ & $2.35 \pm 0.63$ \\
\hline & 98-08 & $1.96 \pm 0.69$ & $2.10 \pm 0.67$ & $2.59 \pm 0.88$ & $3.41 \pm 1.27$ & $2.51 \pm 0.69$ \\
\hline & Overall & $1.89 \pm 0.67$ & $1.89 \pm 0.67$ & $2.40 \pm 0.85$ & $3.45 \pm 1.33$ & $2.43 \pm 0.66$ \\
\hline \multirow{3}{*}{$\begin{array}{l}\text { Suspended solids } \\
\qquad\left(\mathrm{mg} \mathrm{l}^{-1}\right)\end{array}$} & $86-97$ & $3.41 \pm 2.62$ & $3.63 \pm 3.11$ & $3.03 \pm 2.37$ & $3.20 \pm 3.20$ & $3.32 \pm 2.38$ \\
\hline & 98-08 & $3.20 \pm 3.97$ & $2.42 \pm 1.36$ & $2.07 \pm 1.01$ & $2.26 \pm 1.39$ & $2.49 \pm 1.30$ \\
\hline & Overall & $3.31 \pm 3.33$ & $3.05 \pm 2.51$ & $2.57 \pm 1.90$ & $2.75 \pm 2.54$ & $2.92 \pm 1.98$ \\
\hline \multirow{3}{*}{$\begin{array}{l}\mathrm{Chl} a \\
\left(\mu \mathrm{g} \mathrm{l^{-1 }}\right)\end{array}$} & $86-97$ & $9.63 \pm 6.87$ & $9.82 \pm 7.43$ & $6.25 \pm 4.80$ & $3.38 \pm 6.21$ & $7.27 \pm 4.80$ \\
\hline & $98-08$ & $9.33 \pm 6.28$ & $7.58 \pm 4.37$ & $5.20 \pm 2.90$ & $3.13 \pm 2.17$ & $6.31 \pm 3.15$ \\
\hline & Overall & $9.49 \pm 6.58$ & $8.75 \pm 6.25$ & $5.75 \pm 4.03$ & $3.26 \pm 4.72$ & $6.81 \pm 4.12$ \\
\hline \multirow{3}{*}{$\begin{array}{c}\mathrm{NO}_{3}-\mathrm{N} \\
(\mu \mathrm{M})\end{array}$} & $86-97$ & $3.21 \pm 3.17$ & $3.40 \pm 3.74$ & $2.29 \pm 2.15$ & $1.52 \pm 1.43$ & $2.60 \pm 2.30$ \\
\hline & $98-08$ & $1.37 \pm 2.36$ & $1.42 \pm 2.28$ & $1.27 \pm 1.95$ & $1.45 \pm 1.75$ & $1.38 \pm 1.87$ \\
\hline & Overall & $2.33 \pm 2.96$ & $2.45 \pm 3.28$ & $1.80 \pm 2.11$ & $1.48 \pm 1.59$ & $2.02 \pm 2.19$ \\
\hline \multirow{3}{*}{$\begin{array}{c}\mathrm{NH}_{4}-\mathrm{N} \\
(\mu \mathrm{M})\end{array}$} & $86-97$ & $10.13 \pm 6.37$ & $8.27 \pm 5.49$ & $5.61 \pm 3.95$ & $3.56 \pm 3.24$ & $6.89 \pm 4.25$ \\
\hline & $98-08$ & $4.94 \pm 4.39$ & $4.40 \pm 4.67$ & $3.26 \pm 2.53$ & $2.57 \pm 1.76$ & $3.79 \pm 3.09$ \\
\hline & Overall & $7.65 \pm 6.08$ & $6.42 \pm 5.46$ & $4.48 \pm 3.54$ & $3.08 \pm 2.68$ & $5.41 \pm 4.04$ \\
\hline \multirow{3}{*}{$\begin{array}{l}\text { Total inorganic N } \\
\qquad(\mu \mathrm{M})\end{array}$} & $86-97$ & $14.31 \pm 8.79$ & $12.65 \pm 8.00$ & $8.82 \pm 5.27$ & $5.76 \pm 3.69$ & $10.38 \pm 5.86$ \\
\hline & $98-08$ & $6.77 \pm 6.27$ & $6.37 \pm 6.16$ & $5.10 \pm 3.64$ & $4.64 \pm 2.49$ & $5.72 \pm 4.28$ \\
\hline & Overall & $10.71 \pm 8.55$ & $9.64 \pm 7.82$ & $7.04 \pm 4.92$ & $5.22 \pm 3.22$ & $8.15 \pm 5.66$ \\
\hline \multirow{3}{*}{$\begin{array}{c}\text { Total N } \\
(\mu \mathrm{M})\end{array}$} & $86-97$ & $51.53 \pm 19.03$ & $48.58 \pm 18.83$ & $41.39 \pm 19.00$ & $35.10 \pm 26.40$ & $44.15 \pm 18.05$ \\
\hline & $98-08$ & $28.08 \pm 20.20$ & $25.98 \pm 19.14$ & $22.25 \pm 16.91$ & $19.04 \pm 15.90$ & $23.84 \pm 17.64$ \\
\hline & Overall & $40.32 \pm 22.81$ & $37.77 \pm 22.06$ & $32.23 \pm 20.39$ & $27.42 \pm 23.40$ & $34.44 \pm 20.52$ \\
\hline \multirow{3}{*}{$\begin{array}{l}\mathrm{PO}_{4}-\mathrm{P} \\
(\mu \mathrm{M})\end{array}$} & $86-97$ & $1.32 \pm 0.78$ & $1.32 \pm 0.72$ & $0.93 \pm 0.49$ & $0.59 \pm 3.69$ & $1.04 \pm 0.54$ \\
\hline & $98-08$ & $0.30 \pm 0.23$ & $0.31 \pm 0.24$ & $0.30 \pm 0.16$ & $0.33 \pm 0.16$ & $0.31 \pm 0.17$ \\
\hline & Overall & $0.84 \pm 0.77$ & $0.84 \pm 0.74$ & $0.63 \pm 0.49$ & $0.46 \pm 0.30$ & $0.69 \pm 0.55$ \\
\hline \multirow{3}{*}{$\begin{array}{c}\text { Total P } \\
(\mu \mathrm{M})\end{array}$} & $86-97$ & $3.59 \pm 2.13$ & $3.43 \pm 1.58$ & $2.75 \pm 1.37$ & $2.23 \pm 1.42$ & $3.00 \pm 1.43$ \\
\hline & $98-08$ & $1.14 \pm 0.61$ & $1.03 \pm 0.53$ & $0.94 \pm 0.38$ & $0.87 \pm 0.31$ & $0.99 \pm 0.38$ \\
\hline & Overall & $2.42 \pm 2.01$ & $2.28 \pm 1.69$ & $1.89 \pm 1.37$ & $1.58 \pm 1.25$ & $2.04 \pm 1.47$ \\
\hline
\end{tabular}




\begin{tabular}{ccccccc} 
& $86-97$ & $13.56 \pm 8.41$ & $13.96 \pm 7.86$ & $13.90 \pm 6.40$ & $12.97 \pm 5.03$ & $13.60 \pm 6.47$ \\
$\mathrm{SiO}_{2}(\mu \mathrm{M})$ & $98-08$ & $12.64 \pm 7.87$ & $13.24 \pm 7.38$ & $12.68 \pm 6.26$ & $12.44 \pm 5.84$ & $12.75 \pm 6.27$ \\
& Overall & $13.12 \pm 8.16$ & $13.61 \pm 7.63$ & $13.32 \pm 6.35$ & $12.72 \pm 5.43$ & $13.19 \pm 6.38$ \\
& $86-97$ & $0.35 \pm 0.33$ & $0.75 \pm 3.50$ & $0.72 \pm 1.44$ & $0.73 \pm 0.93$ & $0.64 \pm 1.08$ \\
& $98-08$ & $0.30 \pm 0.56$ & $0.41 \pm 0.72$ & $0.69 \pm 2.10$ & $1.16 \pm 2.73$ & $0.64 \pm 1.34$ \\
$\mathrm{NO}_{3} / \mathrm{NH}_{4}$ & Overall & $0.32 \pm 0.45$ & $0.58 \pm 2.58$ & $0.71 \pm 1.78$ & $0.94 \pm 2.01$ & $0.64 \pm 1.21$ \\
& $86-97$ & $12.12 \pm 6.06$ & $10.39 \pm 4.67$ & $10.44 \pm 5.13$ & $11.69 \pm 7.30$ & $11.16 \pm 5.01$ \\
& $98-08$ & $24.99 \pm 18.58$ & $23.16 \pm 16.93$ & $18.69 \pm 12.95$ & $15.44 \pm 10.09$ & $20.57 \pm 12.91$ \\
$\mathrm{TIN} / \mathrm{PO}_{4}$ & Overall & $18.27 \pm 15.00$ & $16.49 \pm 13.94$ & $14.39 \pm 10.52$ & $13.49 \pm 8.93$ & $15.66 \pm 10.70$ \\
& $86-97$ & $1.37 \pm 1.26$ & $1.13 \pm 1.00$ & $0.74 \pm 0.64$ & $0.47 \pm 0.26$ & $0.93 \pm 0.71$ \\
& $98-08$ & $0.73 \pm 0.78$ & $0.62 \pm 0.65$ & $0.49 \pm 0.53$ & $0.41 \pm 0.27$ & $0.56 \pm 0.52$ \\
$\mathrm{TIN} / \mathrm{SiO}_{2}$ & Overall & $1.07 \pm 1.11$ & $0.89 \pm 0.89$ & $0.62 \pm 0.60$ & $0.44 \pm 0.27$ & $0.75 \pm 0.65$ \\
\hline
\end{tabular}


Table 2. Kendall's correlation between phytoplankton variables and various physico-chemical, biological and nutrient ratios parameters at four sampling stations in Tolo Harbour. "Dino" represents dinoflagellates, "Others" represents algal groups other than diatoms or dinoflagellates, "Total" represents total phytoplankton cell counts. "+/-" represents statistical significance at the 0.05 level; "++/--" represents statistical significance at the 0.01 level. Tested values were depth-averaged values except for "Bottom DO" and "Bottom BOD 5 ".

\begin{tabular}{|c|c|c|c|c|c|c|c|c|c|c|c|c|c|c|c|c|c|c|c|c|}
\hline \multirow{3}{*}{ Parameter } & \multicolumn{20}{|c|}{ Station } \\
\hline & \multicolumn{5}{|c|}{ TM3 } & \multicolumn{5}{|c|}{ TM4 } & \multicolumn{5}{|c|}{ TM6 } & \multicolumn{5}{|c|}{ TM8 } \\
\hline & 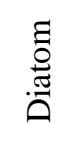 & $\stackrel{\circ}{\bar{\theta}}$ & 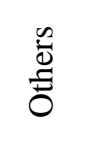 & $\stackrel{\vec{\pi}}{\circ}$ & $\frac{i}{\tilde{J}}$ & 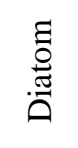 & $\stackrel{\circ}{\stackrel{\emptyset}{a}}$ & $\begin{array}{l}\frac{n}{0} \\
\stackrel{ \pm}{0}\end{array}$ & $\stackrel{5}{0}$ & $\frac{i}{\frac{i}{J}}$ & 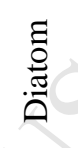 & $\stackrel{\circ}{\bar{\theta}}$ & $\begin{array}{l}\frac{n}{0} \\
\frac{\tilde{J}}{0}\end{array}$ & $\stackrel{5}{0}$ & $\frac{i}{\frac{i}{d}}$ & 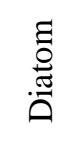 & $\stackrel{\circ}{\stackrel{\Xi}{\circ}}$ & 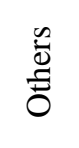 & $\stackrel{\pi}{0}$ & $\frac{i}{i}$ \\
\hline Temperature & ++ & - & & ++ & & ++ & & & ++ & & ++ & & & ++ & & ++ & & + & ++ & \\
\hline $\mathrm{pH}$ & & & -- & & ++ & & & -- & - & ++ & & & & & ++ & & & -- & & + \\
\hline Salinity & & & & & - & & & & & & & - & - & - & -- & & -- & & & - \\
\hline DO & & ++ & & & ++ & & & & & + & -- & & & - & & -- & & & -- & \\
\hline Bottom DO & & ++ & ++ & + & & - & + & ++ & & & -- & & & -- & & -- & & & -- & - \\
\hline $\mathrm{BOD}_{5}$ & & ++ & -- & & ++ & & & & & ++ & & ++ & & + & ++ & & ++ & - & & ++ \\
\hline $\begin{array}{l}\text { Bottom } \\
\text { BOD }_{5}\end{array}$ & & + & & & ++ & & & & - & + & & & & & + & -- & & -- & -- & \\
\hline Secchi Depth & -- & -- & & -- & -- & -- & & + & -- & -- & -- & - & & -- & -- & -- & -- & - & -- & -- \\
\hline $\begin{array}{l}\text { Suspended } \\
\text { solids }\end{array}$ & & ++ & & + & ++ & & + & & & ++ & & & & & ++ & & ++ & & & ++ \\
\hline $\mathrm{NO}_{3}-\mathrm{N}$ & -- & -- & -- & -- & - & -- & & -- & -- & - & & & & & & + & & & & \\
\hline $\mathrm{NH}_{4}-\mathrm{N}$ & -- & & -- & -- & & -- & - & -- & -- & & - & & & & -- & -- & & & - & -- \\
\hline
\end{tabular}




\begin{tabular}{|c|c|c|c|c|c|c|c|c|c|c|c|c|c|c|c|c|}
\hline $\begin{array}{c}\text { Total } \\
\text { inorganic } \mathrm{N}\end{array}$ & -- & - & -- & -- & -- & -- & - & -- & -- & -- & & -- & & & & -- \\
\hline Total N & -- & & -- & -- & + & -- & & -- & -- & ++ & ++ & ++ & & -- & & \\
\hline $\mathrm{PO}_{4}-\mathrm{P}$ & -- & - & -- & -- & - & -- & - & -- & -- & & + & & & - & & - \\
\hline Total P & -- & & -- & -- & & -- & & -- & -- & ++ & & & - & -- & -- & \\
\hline $\mathrm{SiO}_{2}$ & -- & & & & - & -- & & & & & 7 & & & + & + & \\
\hline $\mathrm{NO}_{3} / \mathrm{NH}_{4}$ & - & -- & -- & -- & & & & & - & & & & ++ & & + & \\
\hline $\mathrm{TIN} / \mathrm{PO}_{4}$ & & & ++ & ++ & & & & ++ & - & & & & & + & + & \\
\hline $\mathrm{TIN} / \mathrm{SiO}_{2}$ & - & -- & -- & -- & & - & -- & -- & -- & $p$ & & & & & -- & \\
\hline
\end{tabular}




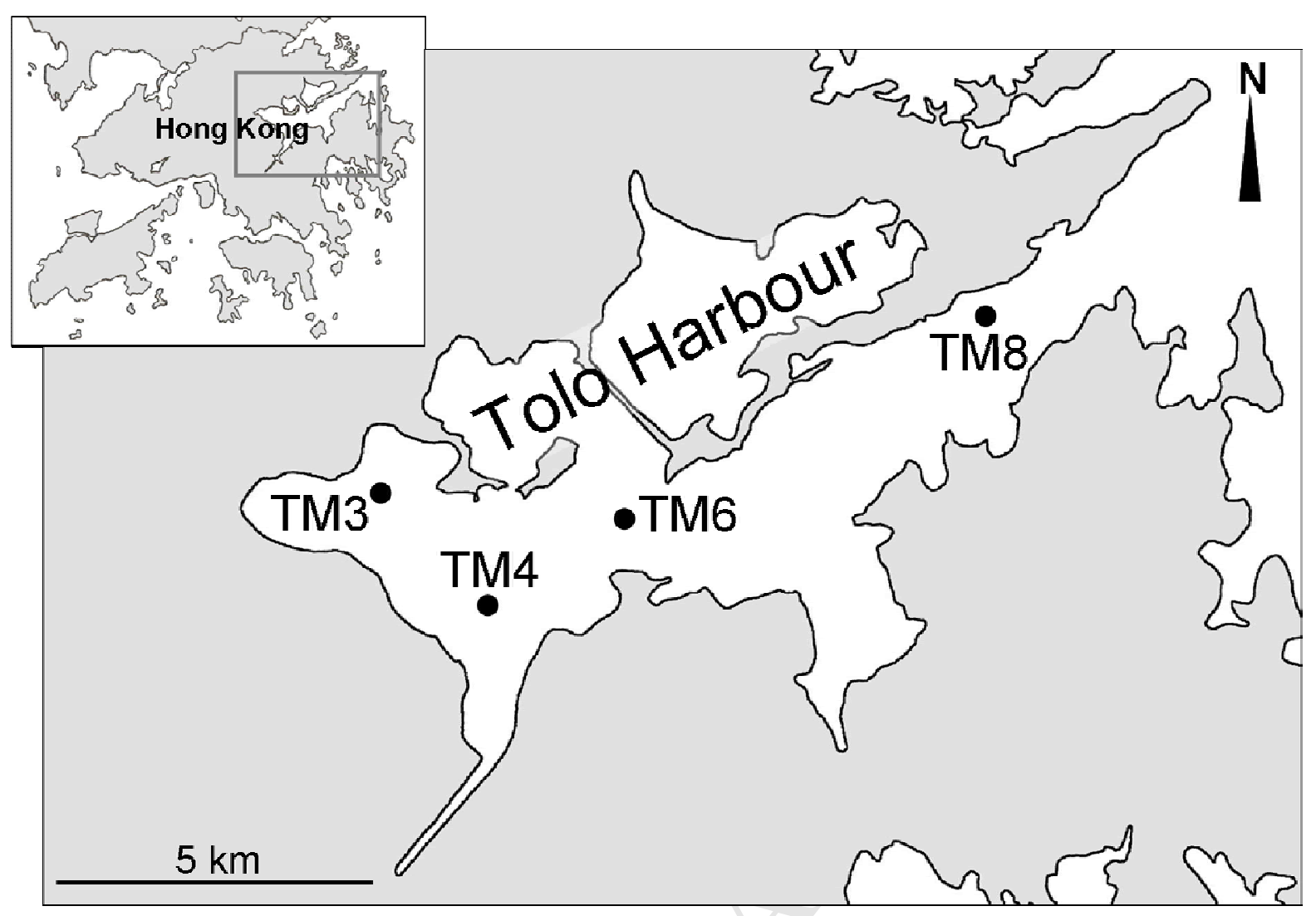

Fig. 1. 

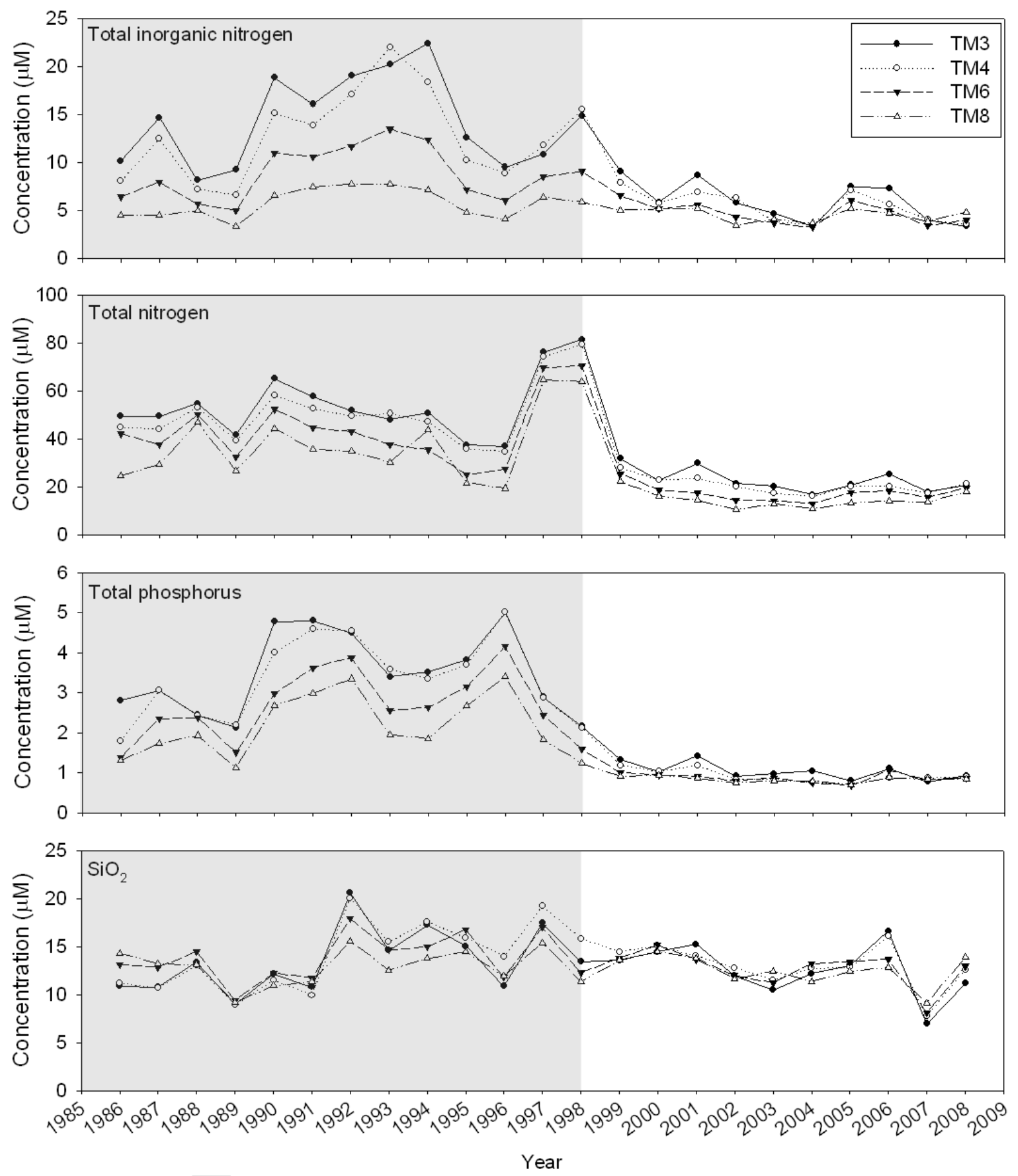

Fig. 2. 

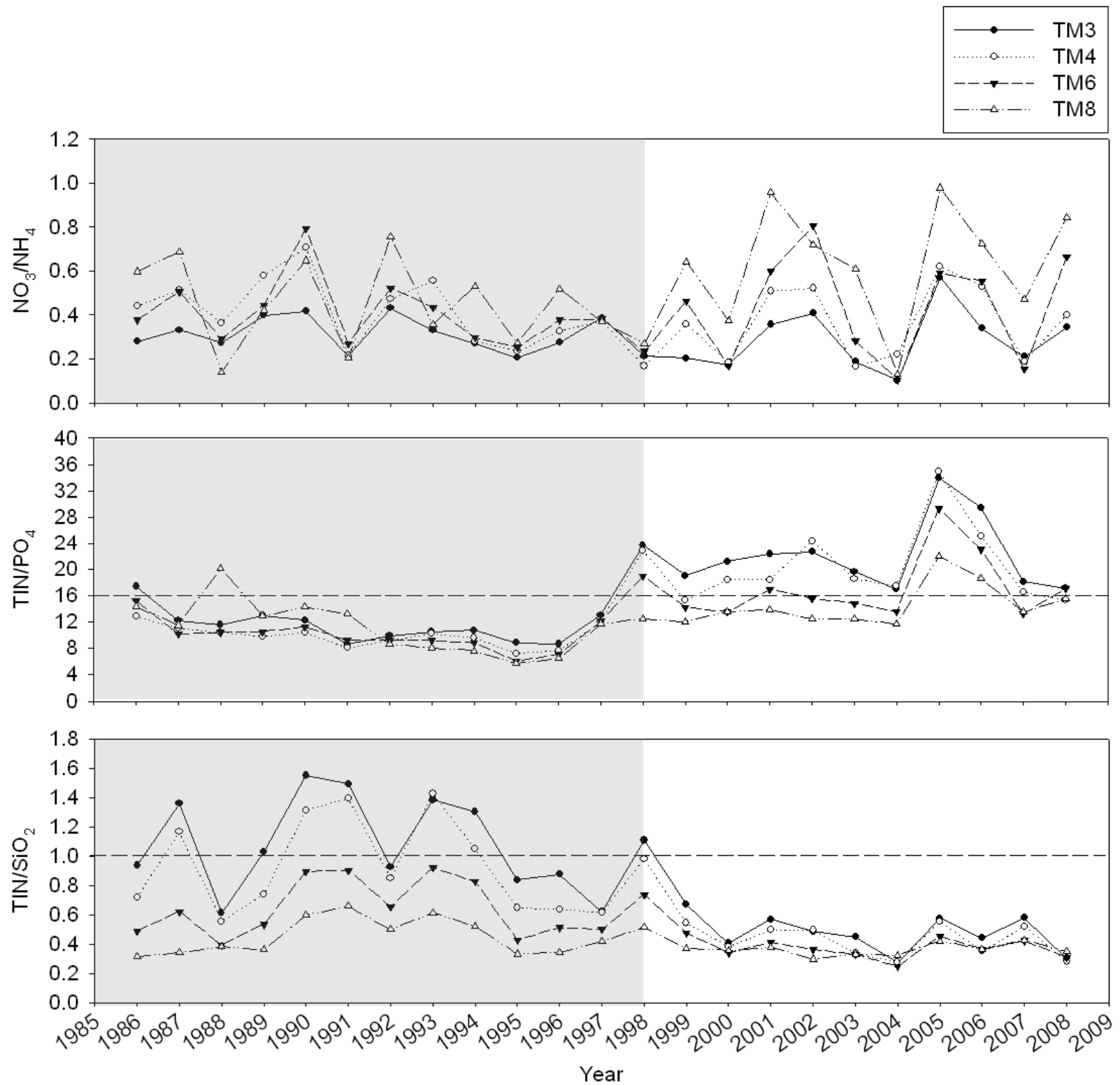

Fig. 3. 


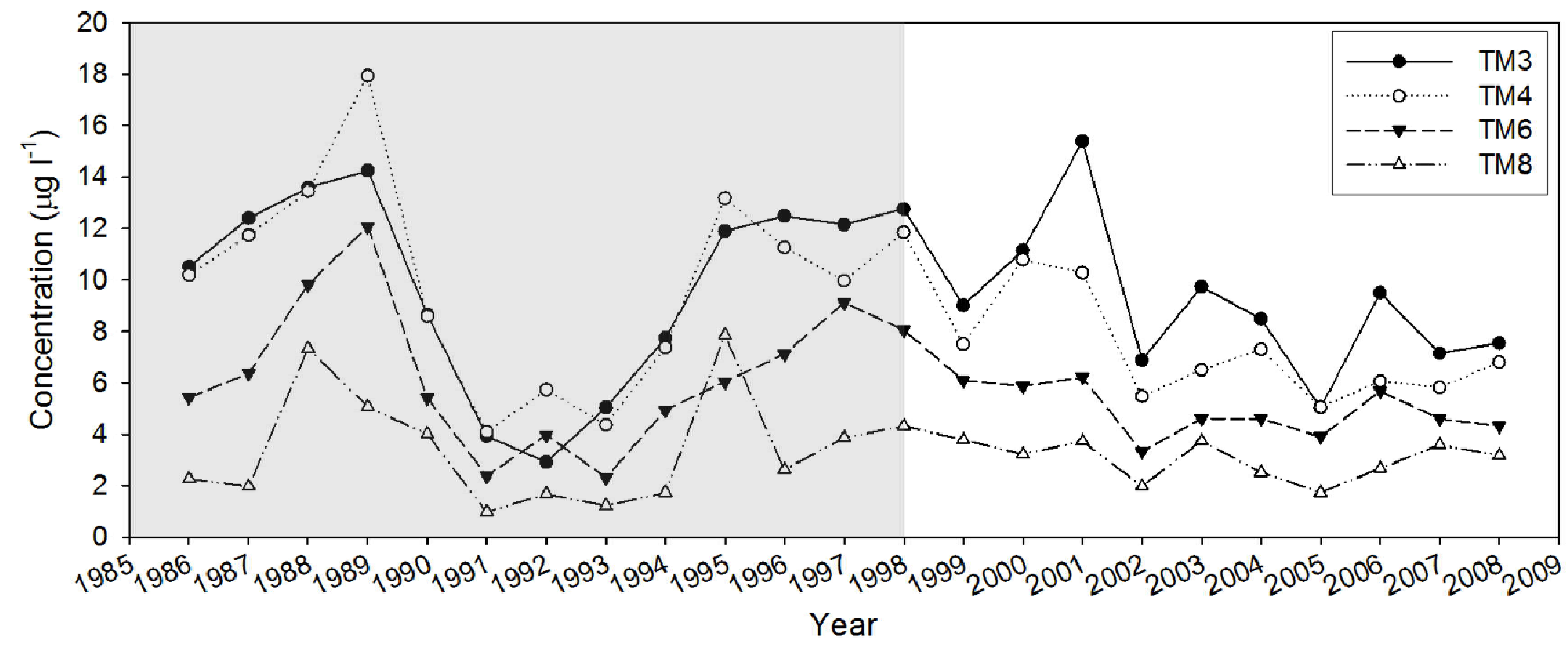

Fig. 4. 

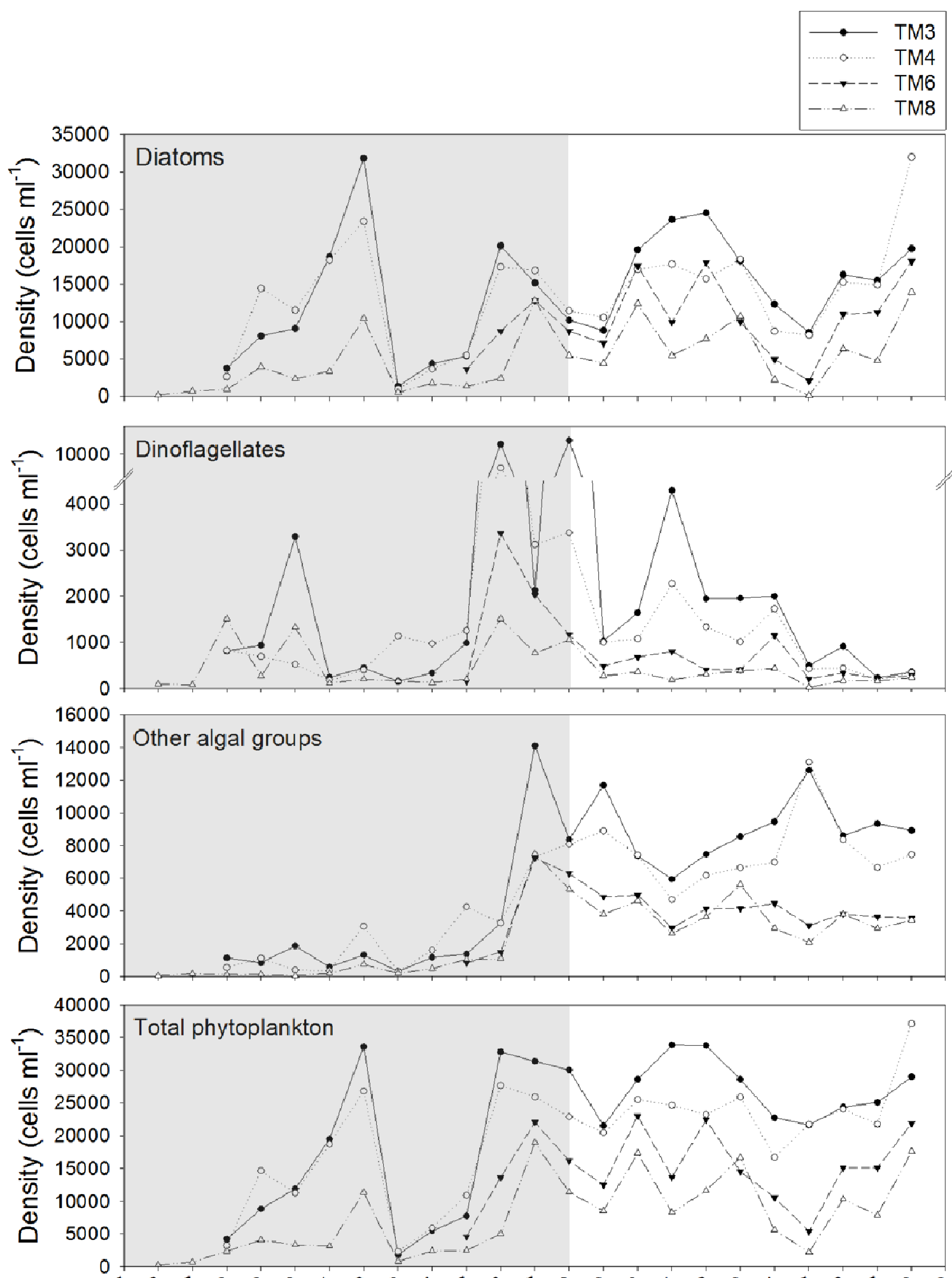

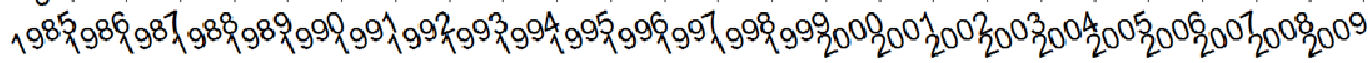
Year

Figure 5. 